\title{
Student Readiness to Accomplish Practical Assignments in Online Learning
}

\author{
Mukti Amini ${ }^{1, *}$ \\ ${ }^{1}$ Universitas Terbuka, Indonesia \\ ${ }^{*}$ Corresponding author. Email: muktiamini@ecampus.ut.ac.id
}

\begin{abstract}
This study aims to analyze the implementation of practical assignments in online learning by students. This research method is a survey through an instrument in the form of a questionnaire with 30 questions developed based on theory. Respondents in this study were 550 students of the Early Childhood Education (ECE) study program in Universitas Terbuka (UT) from various regions in Indonesia. The results of this study are: 1) The covid-19 pandemic caused faceto-face tutorials to change modes to web tutorial so that the practical tasks in the practice court are not too different from the tutorial online (2) Online learning through web tutorial provides several advantages in general: IT capabilities, especially in the use of Microsoft Teams, google drive and youtube, (3) The weaknesses of web tutorial experienced by students in completing tasks: need to signal and pulse enough data, difficulty understanding the explanation of tutors. The suggestion from this research is that students' digital skills and literacy still need to be improved so that they can attend lectures well, especially for online lectures.
\end{abstract}

Keywords: practical assignments, online learning, student readiness

\section{INTRODUCTION}

Nowadays, learning for all educational units is done online, especially in higher education. The covid19 pandemic condition, which is almost evenly distributed around the world, also triggers more intense online learning to reduce direct contact between people. Universitas Terbuka as a university that from its inception implemented the Open and Distance Learning (ODL) system, also implements online learning as part of learning strategies. Especially during this pandemic, online learning is carried out thoroughly, without face-to-face learning.

One of the study programs at UT is the Early Childhood Education (ECE) Program. One of the objectives of the ECE-UT program is for ECE teachers to have the ability to manage educational development activities, which include planning and carrying out development activities, assessing learning processes and learning outcomes and developing students, and improving development activities based on assessment results (UT Catalog, 2016). To achieve this goal, in addition to independent learning, UT provides a variety of academic services for students that include printed teaching materials, non-printed teaching materials, learning assistance services in the form of tutorials such as face-to-face tutorials, online tutorials, and mass media-based tutorials and exam services.

In the ECE-UT Study Program, there are various courses with competencies at a cognitive level 3 to level 6. It's meaning that students must apply and experience the competencies themselves to be achieved. In its design, the course has been designed so that students experience practice for the application of the concept. For this reason, a total of 23 courses in the ECE-UT program are designed as practical courses

From the observations made during the monitoring period of face-to-face tutorials, it was obtained that the implementation of practice for practical courses in ECE-UT in many monitored at UT remote areas has not been implemented (Learning Assistance Center-UT, 2016). Marisa's research (2016) shows that students think that they need a better quality of tutorials related to the provision of learning media, case examples, and concept practices of the material being discussed. Similarly, the face-to-face tutors suggest that courses in the ECE study program should be carried out practices in tutorials. From the 
monitoring of UT Central lecturers with tutors at UT remote areas, it was obtained that tutors sometimes do not practice in the practical subjects that are their responsibility.

The data above shows that there is a possibility that students do not get the learning process outlined in the competencies of the courses, so the students possibly do not achieve the competencies in these courses, both in face-to-face tutorials and online tutorials. Therefore, this research aims to analyze the implementation of practical assignments in tutorial courses practicing in the ECE-UT Study Program.

The separate lecturers and students in the learning process are one of the important characteristics of the distance education system (PJJ) (Simonson, Smaldino \& Zvacek, 2015). The learning process is carried out through media. The learning process referred to here is in the case of lecturers delivering learning materials through the media and students who study the material.

Another important feature in distance education is connecting separation, in this case between students, lecturers, and learning resources (Simonson, Smaldino \& Zvacek, 2015:33). This separation must be bridged through the use of learning strategies that are by student conditions. Learning strategies are defined as tools or techniques available to educators and learning developers to facilitate the learning process (Gagne., Wager., Golas., Keller, 2005). In the context of open and distance education, the learning strategies, in this case, include the media and teaching tools/materials used, the learning methods provided for students, and the time to conduct the learning process.

One of the important types of services to students in distance education institutions is the availability of various modes of learning assistance/tutorials. At the UT, there are 3 types of learning assistance services for students, namely (1) face-to-face tutorials (TTM), (2) online tutorials, and (3) radio/television and mass media tutorials (UT Catalog, 2016). Learning assistance services are provided to help students learn independently in studying the courses they follow, doing assignments, conducting practice, and consulting exams.

As a form of implementation of learning strategies in distance education, practical and practicum courses as well as courses with mandatory guidance, tutorials are carried out face-to-face. This is done as a form of providing a learning experience for students so that they can apply the concept that has been learned into a real skill. The face-to-face tutorial process is designed for interaction between tutors and students in a learning atmosphere.

Research on the analysis of practical assignments in the ECE-UT Study Program is very important to look back at some things. Are the practical assignments that have been designed appropriately to achieve the competence of the course? Can the assignment of practice be carried out? What obstacles are experienced and what improvements can be made?

In the two semesters of 2020.1 and 2020.2, the implementation of practical assignments performed physically in face-to-face tutorial classes cannot be observed and analyzed, because during the pandemic the face-to-face tutorial mode is modified into a synchronous web tutorial utilizing Microsoft teams.

\section{METHOD}

This research uses a survey method. The initial plan, this research method is an evaluation using the CIPP model involved 10 UT remote areas. However, due to the pandemic atmosphere, the instrument was changed to an online questionnaire divided into 30 questions. The population in this study is ECE-UT students who are following the tutorial for the 15 courses above. Sampling in this study using accidental sampling, so anyone who accidentally met with researchers or questionnaires can be used as a sample. Based on the sampling, 550 respondents filled out questionnaires online.

The research was conducted from April to December 2020. Due to the covid 19 pandemic condition, the academic policy at UT has also changed. Face-to-face tutorials are modified into webinar tutorials (Tuweb) using Microsoft Teams. While the online tutorials continue to run as usual. Thus, in system delivery, all tutorials are done online with asynchronous and synchronous models. The data is analyzed quantitatively based on data collected. Data from various documents were analyzed qualitatively descriptive.

\section{RESULT \& DISCUSSION}

Respondents to this study numbered 550 ECE-UT students. With regards to practical assignments that must be uploaded online, can be given the following description.

Table 1. Learning Video Simulation Upload Assignments

\begin{tabular}{|c|l|r|}
\hline No. & Aspects of Email Utilization & Number \\
\hline 1. & $\begin{array}{l}\text { I'm used to making learning } \\
\text { simulation videos }\end{array}$ & 48 \\
\hline 2. & $\begin{array}{l}\text { I've never made a learning } \\
\text { simulation video }\end{array}$ & 192 \\
\hline 3. & $\begin{array}{l}\text { I once made a video but not a } \\
\text { learning simulation }\end{array}$ & 108 \\
\hline 4. & $\begin{array}{l}\text { I find this task very challenging to } \\
\text { my creativity }\end{array}$ & 218 \\
\hline 5. & $\begin{array}{l}\text { I find it very difficult to make } \\
\text { simulation videos }\end{array}$ & 90 \\
\hline 6. & Other & 14 \\
\hline
\end{tabular}

Based on Table 1, it can be seen that the points about 'practical assignments challenging student creativity' ranked highest, while the lowest rank is in the aspect of getting used to making video simulation learning. 
For ECE-UT students who are already ECE teachers, teaching demonstrations in front of the class is not difficult. But making videos from teaching simulations requires new skills, relating to mastery of technology [1]. Video creation also requires adequate media, at least smartphones [2]. So although most students feel challenged by the assignment of making this video, many also claim to have never made a simulation video before and find it difficult.

When it comes to utilizing google drives to store practical assignments especially those with considerable memory capacity, the student picture is as follows.

Table 2. Google Drive Utilization in Practice Assignment Storage

\begin{tabular}{|c|l|r|}
\hline No. & $\begin{array}{l}\text { Aspects of Google Drive } \\
\text { Utilization }\end{array}$ & Number \\
\hline 1. & $\begin{array}{l}\text { I initially did not know what } \\
\text { google drive is }\end{array}$ & 119 \\
\hline 2. & $\begin{array}{l}\text { I've never had an account on } \\
\text { google }\end{array}$ & 57 \\
\hline 3. & $\begin{array}{l}\text { I have a google account but do not } \\
\text { know there is a google drive } \\
\text { facility }\end{array}$ & 95 \\
\hline 4. & $\begin{array}{l}\text { I know google drive but don't } \\
\text { know how to use it }\end{array}$ & 186 \\
\hline 5. & $\begin{array}{l}\text { I know google drive and how to } \\
\text { download documents from there }\end{array}$ \\
\hline 6. & $\begin{array}{l}\text { I can download and upload } \\
\text { documents to and from google } \\
\text { drive }\end{array}$ & 114 \\
\hline 7. & Other & 93 \\
\hline
\end{tabular}

Based on Table 2, it can be seen that the highest rank is that students know about google drive, but do not know how to use it, that is one hundred and eighty-six people. While the lowest order is that students do not yet have a google account, there are about fifty-seven respondents or about ten percent of respondents.

Nowadays google company with a variety of services such as google mail, google drive, google maps, google meet, or google voice is very well known in the community [3]. Of these service variations that people know best is usually Google-based email that is Gmail. While google drive is less widely known. Whereas data storage space in the cloud is now a necessity [4]. Some of the advantages of storage in the cloud such as google drive are: more secure data is not worried about being erased or exposed to viruses, does not burden the storage space on a limited computer, and can be accessed on any device as long as it has a google account [5].

Related to the utilization of youtube to store practical assignments in the form of learning simulation videos, the description of respondents is as follows.
Table 3. Utilization of Youtube in Practice Assignment Video Storage

\begin{tabular}{|l|l|r|}
\hline No. & Aspects of Youtube Utilization & Number \\
\hline 1. & $\begin{array}{l}\text { I previously did not know what } \\
\text { youtube is }\end{array}$ & 16 \\
\hline 2. & $\begin{array}{l}\text { I've never had an account on } \\
\text { youtube }\end{array}$ & 200 \\
\hline 3. & $\begin{array}{l}\text { I know youtube and sometimes } \\
\text { watch from youtube }\end{array}$ & 153 \\
\hline 4. & $\begin{array}{l}\text { I don't know how to upload videos } \\
\text { to youtube }\end{array}$ & 122 \\
\hline 5. & $\begin{array}{l}\text { I have an account on youtube but } \\
\text { never upload videos on youtube }\end{array}$ & 53 \\
\hline 6. & $\begin{array}{l}\text { I've uploaded videos on youtube } \\
\text { several times }\end{array}$ & 14 \\
\hline 7. & Other & \\
\hline
\end{tabular}

Based on Table 3, it can be seen that almost half the respondents are two hundred respondents know about youtube and sometimes watch through youtube. Only a few respondents stated that they did not know about youtube before, which is sixteen respondents.

Youtube as one of the data storage companies with mobile animation is currently in great demand by the public. Especially for millennials who tend to think instantaneously. This mobile audiovisual media like youtube is one of the favorite learning tools for millennials [6]. They no longer learn only through print media like previous generations. Therefore, ECE teachers must also be able to use Youtube as a learning medium for their students [7]. For people who pursue the professional world, nowadays even youtube channels have been utilized in such a way as one of the means to earn money. This can also be done by teachers to earn additional income.

About the relationship between practical assignments in tutorial online or tutorial web and his daily duties as an ECE teacher, student opinions are as follows.

Table 4. Relation of Practical Duties with Duties as Teachers

\begin{tabular}{|c|l|r|}
\hline No. & Aspects & Number \\
\hline 1. & $\begin{array}{l}\text { The assignment supports the } \\
\text { improvement of my competence as a } \\
\text { PAUD teacher }\end{array}$ & 367 \\
\hline 2. & $\begin{array}{l}\text { The assignment is relevant to my } \\
\text { field and I can work according to the } \\
\text { deadline }\end{array}$ & 117 \\
\hline 3. & $\begin{array}{l}\text { Assignments are relevant to my field } \\
\text { but very time consuming to me as a } \\
\text { teacher }\end{array}$ & 49 \\
\hline 4. & $\begin{array}{l}\text { Assignments are irrelevant to my } \\
\text { work as a PAUD teacher }\end{array}$ & 8 \\
\hline 5. & Other & 9 \\
\hline
\end{tabular}


Based on Table 4 it can be seen that the majority of respondents who are sixty-seven percent stated that the practical assignments support the improvement of their competence as ECE teachers. But there are still eight respondents who stated otherwise.

Practical assignments in lectures for practitioners such as ECE teachers are necessary to improve their professional competencies [8]. So it is natural that most students feel that the practical assignments are relevant to their daily duties as teachers. As for those who argue otherwise, it is possible because during the covid-19 pandemic all assignments are not performed in the classroom physically but must be packaged in soft files and uploaded in virtual storage. So the teacher's difficulty is not on the content of the practical assignment but on the ability to package assignments in electronic media and upload them in virtual storage [9].

Related to the obstacles faced by students during practical tasks in online learning, can be seen as follows.

Table 5. Practical Assignment Constraints on Online Learning

\begin{tabular}{|c|l|r|}
\hline No. & Aspects & Number \\
\hline 1. & My area is hard to signal & 222 \\
\hline 2. & Fast signal but the limited data plan & 190 \\
\hline 3. & $\begin{array}{l}\text { Don't know how to use teams or } \\
\text { other apps }\end{array}$ & 24 \\
\hline 4. & $\begin{array}{l}\text { Can not catch the tutor's explanation } \\
\text { properly if only through a } \\
\text { smartphone/laptop }\end{array}$ & 117 \\
\hline 5. & $\begin{array}{l}\text { Difficult to display in a } \\
\text { practical/live demonstration }\end{array}$ & 120 \\
\hline 6. & $\begin{array}{l}\text { Not focused because not in the } \\
\text { classroom with friends physically }\end{array}$ & 72 \\
\hline 7. & Other & 25 \\
\hline
\end{tabular}

Based on Table 5, it can be seen that the biggest obstacle that students can see is the ease of getting adequate signals, which is mentioned by almost half the respondents. The lowest-ranked obstacle is the ability to operate Microsoft teams, which is stated by twenty-four respondents.

Currently, the condition of the internet network in Indonesia is not evenly distributed. There are still many areas that cannot be reached by internet access, especially areas far from the city center. So it is natural that the difficulty of internet access becomes a typical problem of developing countries such as Indonesia [10]. Under normal conditions, UT tries to overcome this problem of internet access difficulties by providing diversification of learning services for students, namely held face-to-face tutorials in addition to online tutorials. But especially during the covid 19 pandemic, all tutorial services are internet-based. No face-to-face tutorials are held adjusting the rules of physical distancing to prevent the spread of the covid 19 virus [11].

Based on the results of the above research, it can be seen that: (1) practical assignments in the form of learning video simulations are felt to greatly trigger student creativity even though only a small percentage of respondents stated that they are used to making learning simulation videos, (2) Many respondents know google drive but do not know how to use it, only about $17 \%$ of respondents can upload and download documents through google drive, (3) Introduction to youtube is mostly just a viewer, not yet uploading content. Less than $10 \%$ of respondents stated that they have uploaded videos several times through youtube, (4) Most respondents say that the practical assignments on tutorial online/tutorial web are related to improving their competence as PAUD teachers, and (5) The main obstacle in the implementation of tutorial online/tutorial web most experienced by students is the adequate signal. The next obstacle is new limited data pulses for internet access.

\section{CONCLUSION}

Some things that can be concluded from the results of this research are as follows; (1) The covid-19 pandemic caused face-to-face tutorials to change modes to web tutorial so that the practical tasks in the practice court are not too different from the tutorial online that is already running. (2) Online learning through web tutorial provides several advantages in general: IT capabilities, especially in the use of Microsoft Teams, google drive and youtube, (3) The weaknesses of web tutorial experienced by students in completing tasks: need to signal and pulse enough data, difficulty understanding the explanation of tutors.

Recommendations that can be submitted related to the above conclusions are as follows: (1) UT needs to facilitate students by providing data pulse assistance to students, either through government funds (if any) or self-funding, (2) It is necessary to think of other modes besides web tutorial for areas that are difficult to reach by internet signals, (3) UT expands the reach of internet access by establishing especially SALUT in areas where the economy is low or hard to reach. SALUT can be used by students in doing practical tasks during tutorials, and (4) The study program needs to design more detailed practical tasks that will be done by students so that it does not appear multi perception of technical instructions for the implementation of tasks that have been made.

\section{REFERENCES}

[1] J. S. Vargas, "Teaching Basic Skills to Mastery with Precision Teaching," in Behavior Analysis for Effective Teaching, Routledge, 2020, pp. 131-155.

[2] M. Berry, "Making Films and Video Art with Smartphones," in Creating with Mobile Media, Springer International Publishing, 2017, pp. 131-151.

[3] T. Ballard, "Google Maps and Google Earth," in 
Google This!, Elsevier, 2012, pp. 113-124.

[4] Q. Yuhuan, "Cloud Storage Technology," Big Data Cloud Innov., vol. 1, no. 1, Jun. 2017, doi: 10.18063/bdci.v1i1.508.

[5] S. Thomas, LM. Jose, A. Stephen, "Multi Cloud Mobile Computing for Secure Storage of Data Using CyptoGraphy," Int. J. Recent Trends Eng. Res., vol. 4, no. 4, pp. 608-611, May 2018, doi: 10.23883/ijrter.2018.4280.uspsq.

[6] C. Vernallis, "Audiovisual Change," in Unruly Media, Oxford University Press, 2013, pp. 155180.

[7] S. Bardaki, "Exploring High School Students' Educational Use of YouTube," Int. Rev. Res. Open Distrib. Learn., vol. 20, no. 2, Apr. 2019, doi: 10.19173/irrodl.v20i2.4074.

[8] O. M. Chorosova, "Methodological Approaches To Study Professional And Personal Well-Being Of Teachers: Professional Competencies," Aug. 2017, doi: 10.15405/epsbs.2017.08.02.16.

[9] C. White, "Replacing Graded Homework Assignments in Statics," 2020, doi: 10.18260/12--35144.

[10] W. Lambrechts and S. Sinha, "Limitations of Last Mile Internet Access in Developing Countries," in Last Mile Internet Access for Emerging Economies, Springer International Publishing, 2019, pp. 41-69.

[11] A. Balleyer, "Face Mask Mandate and Compliance with Physical Distancing Recommendations During the COVID-19 Pandemic." American Economic Association, May 2020, doi: 10.1257/rct.5831-1.0. 